\title{
Online Learning: The Role of Academic Self-Efficiency in Creating Academic Flow
}

\author{
Eka Apristian Pantu' \\ ${ }^{1}$ Fakultas Ilmu Tarbiyah dan Keguruan, Institut Agama Islam Negeri \\ Sultan Amai Gorontalo \\ 1 ekapantu@iaingorontalo.ac.id
}

\begin{abstract}
The spread of Covid-19 encourages educational institutions to maximize online learning. Online learning can work well if students can focus on learning. The ability to focus on learning is known as academic flow. This study aims to explain the effect of academic self-efficacy on flow academic in online learning. This research involves 296 participants who were selected by incidental sampling. The instruments used in this research are the self-efficacy scale and flow short scale, which was analyzed using linear regression techniques. The results show that academic self-efficacy significantly affects academic flow $(\beta=0,609 ; p=<0,001)$. The result means that an increase in academic self-efficacy will also increase academic flow.
\end{abstract}

Keywords: academic self-efficacy; academic flow, online learning

\section{Introduction}

The spread of Covid-19 in all parts of the world has changed our way of life. The need to stay healthy requires individuals to keep a distance when leaving the house and always wear a mask. In addition, some countries choose to implement a lockdown. The massive spread of Covid-19 also impacts the world of education (Aji, 2020).

In the world of education, Covid-19 has resulted in the closure of educational facilities, both school and college institutions. The closure of this facility was followed by a policy to implement online learning. Rapid system changes without prior preparation have resulted in the unpreparedness of educational institutions to carry out online learning. As a result, online learning that is carried out only moves face-to-face learning to a virtual space.

Online learning that is applied also presents its problems. Network instability and difficulty concentrating are problems that individuals complain about in online learning (Handayani, 2020). Network instability occurs due to uneven development in Indonesia. Meanwhile, the concentration problem can be solved if the individual succeeds in achieving the academic flow condition. In addition, flow is also reported to have a positive effect on the cumulative achievement index (Adil, Ameer, \& Ghayas, 2019).

Flow is a condition in which individuals perform their duties smoothly in doing these tasks. Individuals are also fully dedicated to the task to ignore hunger, fatigue, and feelings of discomfort (Nakamura and Csikszentmihalyi, 2002). Therefore, an educator should be able to design appropriate learning methods for individuals to improve academic flow (Ijubin-Golub, Rijavec, \& Olcar, 2020; Zhang, Lou, Zhang, \& Zhang, 2019). Among the methods that educators can provide to improve academic flow are by providing feedback (Ellwood \& Abrams, 2018; Yu, Wu, \& Huang, 2018) and the Montessori method for orienting and motivating adults (MOMA) (Aini, Ilfiandra, \& Saripah, 2019) 
When individuals succeed in achieving academic flow conditions, the learning concentration disorders experienced by individuals in online learning can be resolved. This is reinforced by research conducted by Santosa (2015), who found that academic flow can occur in online learning. Individuals with a good academic flow are reported to have good learning achievement (Putri, 2016), low anxiety (Mao, Yang, Bonaiuto, Ma, and Harmat, 2020), and reduce individual procrastination (Hidayati and Aulia, 2019; Pradana \& Putri, 2019).

Flow is easier to achieve when individuals carry out organizational activities when compared to academic activities (Rosiana et al., 2015). Individuals can still feel academic flow even though individuals are busy organizing and working (Mayangsari \& Pratiwi, 2019). Based on these findings, efforts should be found that can improve academic flow, especially in online learning

Flow can occur due to internal and external factors. External factors that can cause academic flow include interactive learning ( $\mathrm{Ha}$ and $\mathrm{Im}, 2020)$, crowd levels (Liu and Csikszentmihalyi, 2020), and social support (Amira \& Muhid, 2020). In addition, the role of parents can also affect the occurrence of academic flow (Kemala, Safitri, and Zwagery, 2018).

In addition to external factors, academic flow can also be influenced by internal factors such as self-efficacy (Diola \& Mudjiran, 2019; Purwati \& Akmaliyah, 2016), self-esteem (Djau \& Cahyono, 2017), religiosity (Alfarabi, Saraswati, and Dayakisni, 2017 ), academic stress (Gatari, 2020), optimism (Suryaningsih, 2016) perfectionism (Ijubin-Golub, Rijavec, and Jurjec, 2018), and achievement motivation (Arif, 2013).

Academic flow can occur with academic self-efficacy. Academic selfefficacy is the belief that an individual has that he can complete the tasks that are his academic demands well. Individuals who have good self-efficacy are reported to have good academic achievements (Villafane, $\mathrm{Xu}$, and Raker, 2016). In addition, individuals who have good self-efficacy can make adjustments in lectures (Mutar, Mohammad, and Hmmud, 2020; Wijaya \& Pratitis, 2012). Low self-efficacy also impacts the individual's low academic persistence (Cassidy, 2015) and problems in internet use (Odaci, 2011).

A study conducted by Diola and Mudjiran (2019) conducted on Bidikmisi FIP UNP students found that their selfefficacy contributed to academic flow. This result is reinforced by another study conducted by Mesurado, Richaud, and Mateo (2016), which found that selfefficacy affected academic flow. These studies that use face-to-face learning methods make researchers interested in examining how academic self-efficacy influences academic flow in online learning. Research is becoming increasingly attractive because academic self-efficacy in face-toface learning is higher than in online learning (Dayne, Harabayashi, Seli, \& Reidobolt, 2016).

Based on the description above, the purpose of this study is to examine how the influence of academic self-efficacy on academic flow in online learning. Meanwhile, the benefits that can be obtained from this research are enriching knowledge about academic flow in online learning so that educators can determine the suitable method for conducting online learning.

The sudden changes due to the Covid-19 pandemic resulted in individuals not being ready to switch from face-to-face learning to online learning. However, as time goes by, individuals are getting used to and become competent in online learning to impact academic self-efficacy, which also increases (Lee, 2016; Septiana, 2020). When individual academic self-efficacy is high, individuals have high learning goals and expectations to become serious in learning and create conditions for academic flow 
(Elias, Mustafa, Roslan, and Noah, 2010). Based on the description above, the hypothesis proposed in this study is that self-efficacy is a predictor of academic flow in online learning.

\section{Methods}

\section{Participants}

The participants in this study were active Indonesian students who took part in online learning. In 2019, the ministry recorded 7,339,164 active students throughout Indonesia (Ministry of Research, Technology and Higher Education, 2018). Meanwhile, in this study, the subject of the research sample amounted to 296 students where the selection of subjects used the incidental sampling method. For a population above $1,000,000$ and with an error rate of $10 \%$, the number of samples is 272 , which is the minimum number of samples needed (Sugiyono, 2013).

Research design

The design used in this research is correlational quantitative. This design was chosen to find a causal relationship between academic self-efficacy variables and academic flow.

\section{Instruments}

The independent variable in this study is academic self-efficacy. This variable was measured using the motivated strategies for learning questionnaire (MSLQ) scale from Pintrich and Groot (1990), where the items used were only those on the aspect of self-efficacy. The original scale of Pintrich and Groot totalled nine items. Then tested the validity using factor analysis so that the number of items remaining and used in this study amounted to eight items using the Likert model. The reliability of this scale is 0.905 . An example of an item from this scale is "I expect to better score on the online learning system than other friends".
Meanwhile, the dependent variable in this study is academic flow. The flow shortscale measured this variable from Rheinberg, Vollmeyer, and Engeser and the addition of items from Abuhamdeh (Engeser, 2012). The total items on this scale are thirteen items, then after being adapted into Indonesian and testing the validity using factor analysis, the remaining seven items with the reliability of 0.854 . This scale is a Likert scale with five answer choices. An example of an item from this scale is "I am very concentrated when learning online".

Analysis

The analysis was carried out using the linear regression method with the help of JASP software (JASP Team, 2020).

\section{Findings}

The academic self-efficacy variable has a score between nine and forty with an average of 26,176 and a standard deviation of 6.448 . Based on the average, the category of individual academic self-efficacy scores is in the medium category. Meanwhile, the academic flow variable ranges from seven to 34 , where the average is 19.716 , and the standard deviation is 5.911. Individual academic flow scores, on average, are in the medium category.

Table 1.

Descriptive Statistics

\begin{tabular}{lccl}
\hline \multicolumn{1}{c}{ Variable } & Mean & SD & Category \\
\hline $\begin{array}{l}\text { Academic Self- } \\
\text { Efficacy }\end{array}$ & 26,176 & 6,448 & Medium \\
$\begin{array}{l}\text { Academic } \\
\text { Flow }\end{array}$ & 19,716 & 5,911 & Medium \\
\hline
\end{tabular}

Based on the results of regression analysis (Table 2), it was found that academic self-efficacy had a significant effect on the academic flow in online learning $(F=231,669, p=<0.01)$. This finding means that academic self-efficacy is 
a predictor of academic flow. Every $1 \mathrm{SD}$ increase in academic self-efficacy will lead to an increase in the academic flow by 0.664. The academic self-efficacy variable can predict academic flow in online learning by $44.1 \%$, where the other $55.9 \%$ is influenced by other variables not examined in this study.

Table 2.

Regression Result

\begin{tabular}{lcccc}
\hline Predictor & $\mathbf{R}^{2}$ & $\mathbf{F}$ & $\mathbf{p}$ & $\boldsymbol{\beta}$ \\
\hline Academic & & & $<$ & \\
Self- & 0,441 & 231,699 &, 01 & 0,664 \\
Efficacy & & & & \\
\hline
\end{tabular}

\section{Discussion}

This study indicates that there is a significant and positive effect of academic self-efficacy on academic flow. This shows that the academic self-efficacy that exists in individuals can be a predictor of their academic flow. These results are consistent with previous research conducted by Joo, Oh, and Kim (2015), who found that academic self-efficacy also affects academic flow in online learning situations.

This can happen because, in online learning, individuals are required to manage their learning independently. This is inseparable from the lack of control that teachers can give to individuals when learning takes place. If individuals can regulate themselves well, individuals will avoid internet abuse and show good selfefficacy (Hu et al., 2019; Lee, Watson), \& Watson, 2020; Odaci, 2011). The higher the academic self-efficacy in the individual, the higher the academic flow in online learning experienced by the individual (Diola \& Mudjiran, 2019).

Another thing that causes academic self-efficacy to affect academic flow in online learning is that individuals are required to be actively involved in learning in online learning. When teachers make online learning more active, individuals will be interested in learning (Ha \& Im, 2020). Individuals with a high interest in learning will be much involved in the classroom to interact with classmates. The more intense the interactions in online learning, the higher the academic self-efficacy shown (Martha, 2015; Shen, Cho, Tsai, and Marra, 2013). Individuals who show high selfefficacy become more resilient in learning which is indicated by their high resilience (Anggraini, Wahyuni, \& Soejanto, 2017). The higher the resilience possessed, the more it can bring up the academic flow in the individual (Primasari, Mayangsari, \& Zwagery, 2019).

In addition to the two factors above, the experience factor in participating in online learning is also the cause of the influence of academic self-efficacy on academic flow. At the beginning of the Covid-19 pandemic, individuals experienced unpreparedness and not a few individuals were taking online learning for the first time, and this had an impact on individual academic self-efficacy in online learning, which was lower when compared to individual academic self-efficacy in faceto-face learning methods (Dayne, Harabayashi, Seli, and Reidobolt, 2016). As time goes by, individuals are getting used to following online learning. The experience of participating in online learning increasingly increases individual academic self-efficacy (Lee, 2016; Santoso, 2014). High academic self-efficacy has an impact on individual achievement motivation (Amir, 2016). Individuals with high achievement motivation result in high academic flow in the individual (Arif, 2013). In this study, there were $55.9 \%$ unexplained variables. One of the other variables not tested in this study is the personality factor. Adaptive perfectionist personality is related to academic flow, while maladaptive perfectionists show the opposite relationship (Ijubin-Golub, Rijavec, \& Jurjec, 2018). In addition to personality, the variable also not explained in this study is cyberloafing, which has a negative 
relationship with the academic flow (Yuwanto, 2018).

This research is also not free from existing limitations. The nonimplementation of screening on how long individuals have been doing online learning or how familiar individuals are with the learning applications used are limitations in this study. For further researchers who want to continue research, they can use personality variables in further research. In addition, addiction to the use of the internet and online games can also be considered a predictor of academic flow in online learning.

\section{Conclusion}

Based on the results of the study, several conclusions can be drawn as follows:

1. Academic self-efficacy is a predictor of academic flow in online learning.

2. An attractive learning method is one of the keys to success in online learning.

3. Skills in carrying out online learning can support the success of online learning

The implications and suggestions based on the research that has been done are:

1. Learners are expected to be able to adapt to online learning methods in order to achieve high academic selfefficacy conditions.

2. Educators prepare the most appropriate teaching methods in online situations and prioritize interactive learning models. This is because, in interactive learning, there is an intense two-way interaction between educators and learners. Educators can provide social support or motivate learners in the learning process to increase their academic self-efficacy.

3. Educational institutions can provide training for educators and students in online-based learning applications to realize the performance experience and vicarious experience for students.

\section{References}

Adil, A., Ameer, S., \& Ghayas, S. (2019). Impact of Academic Psychological Capital on Academic Achievement among University Undergraduates: rules of flow and self-handicapping behavior. PsyCh Journal, 9(1), 56-66.

Aini, N. Q., Ilfiandra, \& Saripah, I. (2019). Aspek-Aspek Flow Akademik. Journal of Innovative Counseling: Theory, practice, \&o research, 3(2), 43-51.

Aji, R. H. (2020). Dampak Covid-19 pada Pendidikan di Indonesia: Sekolah, Keterampilan, dan Proses Pembelajaran. Salam: Jurnal Sosial dan Budaya Syar-i, 7(5), 395-402.

Alfarabi, A., Saraswati, P., \& Dayakisni, T. (2017). Religiusitas dengan Flow Akademik pada Siswa. Psikis, 3(2), 145-154.

Amir, H. (2016). Korelasi Pengaruh Efikasi Diri dan Manajemen Diri terhadap Motivasi Berprestasi pada Mahasiswa Pendidikan Kimia Universitas Bengkulu. Mapen, 10(4), 336-342.

Amira, R. D., \& Muhid, A. (2020). SelfRegulated Learning, Self-Esteem, Dukungan Sosial, dan Flow Akademik. Indonesian Psychological Research, 2(2), 65-74.

Anggraini, O. D., Wahyuni, E. N., \& Soejanto, L. T. (2017). Hubungan antara Efikasi Diri dengan Resiliensi Menghadapi Ujian pada Siswa Kelas XII SMAN 1 Trawas. Jurnal Konseling Indonesia, 2(2), 50-56.

Arif, K. (2013). Hubungan antara Motivasi Berprestasi dan Flow Akademik. Calyptra, 2(1), 1-12.

Cassidy, S. (2015). Resilience Building in Students: the role of academic selfefficacy. Frontiers in Psychology, 6, 1-14. 
Dayne, N., Hirabayashi, K., Seli, H., \& Reidobolt, W. (2016). the Examination of Academic SelfEfficacy and Academic Help Seeking of Higher Education Students Taking an on Campus or Online General Education Course in Family and Consumer Sciences. Journal of Family and Consumer Sciences Education, 33(2), 13-24.

Diola, S., \& Mudjiran. (2019). Kontribusi Self-Efficacy terhadap Flow Akademik pada Mahasiswa Bidikmisi FIP UNP. Jurnal Riset Psikologi, 2019(3), 1-11.

Djau, N. R., \& Cahyono, R. (2017). Hubungan antara Self-Esteem dengan Flow Akademik pada Siswa Cerdas Istimewa. Jurnal Psikologi Pendidikan dan Perkembangan, 6(1), 65-71.

Elias, H., Mustafa, S. M., Roslan, S., \& Noah, S. M. (2010). Examining Potential Relationships Between Flow and Motivational Forces in Malaysian Secondary School Students. Procedia Social and Behavioral Sciences, 9, 20422046.

Ellwood, R., \& Abrams, E. (2018). Student's Social Interaction in Inquiry-Based Science Education: How experiences of flow can increase motivation and achievement. Cultural Studies of Science Education, 13(3), 395427.

Engeser, S. (2012). Advances in Flow Research. New York: Springer.

Gatari, A. (2020). Hubungan Stres Akademik dengan Flow Akademik pada Mahasiswa. Cognicia, 8(1), 78-89.

Ha, Y., \& Im, H. (2020). the Role of an Interactive Visual Learning Tool and its Personalizability in Online Learning: Flow experience. Online Learning Journal, 24(1), 205-226.

Handayani, L. (2020). Keuntungan, Kendala dan Solusi Pembelajaran
Online Selama Pandemi Covid-19 : Studi Ekploratif di SMPN 3 Bae Kudus. Journal Industrial Engineering \& Management Research, 1(2), 15-23.

Hidayati, N., \& Aulia, L. a.-A. (2019). Flow Akademik dan Prokrastinasi Akademik. Jurnal Psikologi, 6(2), 128144.

Hu, E., Stavropoulos, V., Anderson, A., Clarke, M., Beard, C., Papapetrou, S., et al. (2019). Assesing Online Flow Across Cultures: a two-fold measurement invariance study. Frontiers Psychology, 10, 1-16.

Ijubin-Golub, T., Rijavec, M., \& Jurjec, L. (2018). Flow in the Academic Domain: the role of perfectionism and engagement. Asia-Pacific Education Research, 27(2), 99-107.

Ijubin-Golub, T., Rijavec, M., \& Olcar, D. (2020). Student Flow and Burnout: the role of teacher autonomy support and student autonomous motivation. Psychological Studies, 65, 145-156.

JASP Team (2020). JASP (Version 0.14.1) [Computer software].

Joo, Y. J., Oh, E., \& Kim, S. M. (2015). Motivation, Instructional Design, Flow, and Academic Achievement at a Korean Online University: A structural. Journal of Computing in Higher Education, 27, 28-46.

Kemala, E., Safitri, J., \& Zwagery, R. V. (2018). Hubungan antara Persepsi Keterlibatan Ayah dalam Pengasuhan dengan Flow Akademik pada Peserta Didik Kelas IX SMP Negeri 1 Banjarbaru. Kognisia, 1(2), 60-64.

Kementerian Riset, T. d. (2018, Desember). Statistik Pendidikan Tinggi 2019. Retrieved Juli 12, 2021, from Pangkalan Data Pendidikan Tinggi (PPDIKTI) Kementerian Pendidikan, Kebudayaan, Riset, dan Teknologi: https://pddikti.kemdikbud.go.id/asset/da 
ta/publikasi/Statistik\%20Pendidikan\%2 OTinggi\%20Indonesia\%202019.pdf

Lee, C.-Y. (2016). Changes in Self-Efficacy and Task Value in Online Learning. Distance Education, 36, 59-79.

Lee, D., Watson, S. L., \& Watson, W. R. (2020). the Relationships Between Self Efficacy, Task Value, and Self Regulated Learning Strategies in Massive Open Online Courses. International Review of Research in Open and Distributed Learning, 21(1), 24-39.

Liu, T., \& Csikszentmihalyi, M. (2020). Flow among Introverts and Extraverts in Solitary and Social Activities. Personality and Individual Differences, 167, 1-8.

Mao, Y., Yang, R., Bonaiuto, M., Ma, J., \& Harmat, L. (2020). Can Flow Alleviate Anxiety? the roles of academic selfefficacy and self-esteem in building psychological sustainability and resilience. Sustainability, 20, 1-17.

Martha, J. A. (2015). Peningkatan Hasil Belajar, Aktivitas, dan Efikasi Diri melalui Pembelajaran Model Carousel Feedback dan Showdown pada Mata Pelajaran Kewirausahaan. Jurnal Konseling Indonesia, 1(1), 68-75.

Mayangsari, M. D., \& Pratiwi, S. D. (2019). Flow Akademik pada Mahasiswa yang Aktif Berorganisasi dan Bekerja. Psycho Holistic, 1(2), 47-52.

Mesurado, B., Richaud, M. C., \& Mateo, N. J. (2016). Engagement, Flow, SelfEfficacy, and Eustress of University Students: a cross-national comparison between the Philippines and Argentina. the Journal of Psychology, 150(3), 281-299.

Mutar, Q. M., Mohammad, H. M., \& Hmmud, S. H. (2020). Academic Achievement and Its Relation with Self-Efficacy and Academic Adjustment in EFL Class. International
Journal of Multicultural and Multireligious Understanding, 7(5), 1-13.

Nakamura, J., \& Csikszentmihalyi, M. (2002). The Concept of Flow. In C. R. Snyder, \& S. J. Lopez, Handbook of Positive Psychology (pp. 89-105). Oxford: Oxford University Press.

Odaci, H. (2011). Academic Self-Efficacy and Academic Procrastination as Predictors of Problematic Internet Use in University Students. Computers and Education, 57, 1109-1113.

Pintrich, P. R., \& Groot, E. V. (1990). Motivational and Self-Regulated Learning Components of Classroom Academic Performance. Journal of Educational Psychology, 82(1), 33-40.

Pradana, A. S., \& Putri, D. E. (2019). Flow experience dan Prokrastinasi Akademik pada Mahasiswa. Jurnal Psikologi, 12(1), 44-56.

Primasari, L. E., Mayangsari, M. D., \& Zwagery, R. V. (2019). Hubungan Resiliensi dengan Flow Akademik pada Siswa di Daerah Lahan Gambut. Kognisia, 2(1), 99-104.

Purwati, E., \& Akmaliyah, M. (2016). Hubungan antara Self-Efficacy dengan Flow Akademik pada Siswa Akselerasi SMPN 1 Sidoarjo. Psympathic, 3(2), 249-260.

Putri, E. M. (2016). Hubungan antara Dukungan Sosial dan Flow Akademik dengan Prestasi Belajar Matematika Siswa SMA. Calyptra, 5(1), 1-21.

Rosiana, D., Sumaryanti, I. U., Diantina, F. P., Dwi, A., Fajrina, Dwiyanti, E. P., et al. (2015). Pengalaman Flow: mengantarai kesuksesan akademik dan organisasi. SNaPP2015 Sosial, Ekonomi, dan Humaniora (pp. 148152). Bandung: Universitas Islam Bandung.

Santosa, P. I. (2015). Student Engagement with Online Tutorial: a perspective on 
flow theory. International Journal of Emerging Technologies in Learning, 10(1), 60-67.

Santoso, M. (2014). Self-Efficacy dan Flow Akademik ditinjau dari Temporal Motivation Theory pada Mahasiswa Fakultas Psikologi. Calyptra, 3(1), 112.

Septiana, Y. (2020). Survei Efikasi Diri Mahasiswa Prodi Pendidikan Akuntansi pada Masa Pembelajaran Jarak Jauh. Jurnal Ekonomi dan Pendidikan, 17(2), 83-97.

Shen, D., Cho, M.-H., Tsai, C.-L., \& Marra, R. (2013). Unpacking Online Learning Experiences: Online learning self-efficacy and learning satisfaction. Internet and Higher Education, 19, 10-17.

Sugiyono. (2013). Metode Penelitian Kuantitatif, Kualitatif, dan Kombinasi (Mixed Methods). Bandung: Alfabeta.

Suryaningsih, A. (2016). Hubungan Antara Optimisme dan Self-Efficacy dengan Flow Akademik Siswa SMA. Calyptra, 5(1), 1-22.

Villafane, S. M., Xu, X., \& Raker, J. R. (2016). Self-Efficacy and Academic Performance in First-semester Organic Chemistry: testing a model of reciprocal causation. Chemistry Education Research and Practice, 17, 973984.

Wijaya, I. P., \& Pratitis, N. T. (2012). Efikasi Diri Akademik, Dukungan Sosial Orang Tua dan Penyesuaian Diri Mahasiswa dalam Perkuliahan. Persona, 1(1), 40-52.

Yu, F.-Y., Wu, W.-S., \& Huang, H.-C. (2018). Promoting Middle School Students' Learning Motivation and Academic Emotions via StudentCreated Feedback for Online Student-Created Multiple-Choice Questions. Asia Pacific Education Research, 27(5), 395-408.
Yuwanto, L. (2018). Academic Flow and Cyberloafing. Psychology Research, 8(4), 173-177.

Zhang, J., Lou, X., Zhang, H., \& Zhang, J. (2019). Modelling Collective Attention in Online and Flexible Learning Environments. Distance Education, 40(2), 278-301. 